\title{
Communication \\ Two New Metabolites from the Endophytic Fungus Alternaria sp. A744 Derived from Morinda officinalis
}

\author{
Ying Wang ${ }^{1,2,+}$, Hong-Xin Liu ${ }^{1,+}$, Yu-Chan Chen ${ }^{1}$, Zhang-Hua Sun ${ }^{1}$, Hao-Hua Li ${ }^{1}$, Sai-Ni Li ${ }^{1}$, \\ Ming-Li Yan ${ }^{2}$ and Wei-Min Zhang ${ }^{1, *}$ \\ 1 State Key Laboratory of Applied Microbiology Southern China, Guangdong Provincial Key Laboratory of \\ Microbial Culture Collection and Application, Guangdong Open Laboratory of Applied Microbiology, \\ Guangdong Institute of Microbiology, Guangzhou 510070, China; wangyinghx@163.com (Y.W.); \\ hxinliu1225@163.com (H.-X.L.); yuchan2006@126.com (Y.-C.C.); sysuszh@126.com; (Z.-H.S.); \\ hhli100@126.com (H.-H.L.); lisn@gdim.cn (S.-N.L.) \\ 2 School of Chemistry and Chemical Engineering, Hunan University of Science and Technology, \\ Xiangtan 411100, China; mlyan@hnust.edu.cn \\ * Correspondence: wmzhang@gdim.cn; Tel.: +86-136-0049-9900; Fax: +86-20-8768-8612 \\ + These authors contributed equally to this work. \\ Academic Editor: Derek J. McPhee \\ Received: 1 April 2017; Accepted: 4 May 2017; Published: 8 May 2017
}

\begin{abstract}
Two new compounds isobenzofuranone A (1) and indandione B (2), together with eleven known compounds (3-13) were isolated from liquid cultures of an endophytic fungus Alternaria sp., which was obtained from the medicinal plant Morinda officinalis. Among them, the indandione (2) showed a rarely occurring indanone skeleton in natural products. Their structures were elucidated mainly on the basis of extensive spectroscopic data analysis. All of the compounds were evaluated with cytotoxic and $\alpha$-glucosidase inhibitory activity assays. Compounds $\mathbf{1 1}$ and $\mathbf{1 2}$ showed significant inhibitory activities against four tumor cell lines; MCF-7, HepG-2, NCI-H460 and SF-268, with IC 50 values in the range of 1.91-9.67 $\mu \mathrm{M}$, and compounds $4,5,9,10,12$ and 13 showed excellent inhibitory activities against $\alpha$-glucosidase with $\mathrm{IC}_{50}$ values in the range of $12.05-166.13 \mu \mathrm{M}$.
\end{abstract}

Keywords: Alternaria sp.; endophytic fungus; Morinda officinalis; cytotoxicity; $\alpha$-glucosidase inhibitory

\section{Introduction}

Endophytic fungi have been considered a rich source of structurally novel and bioactive diverse metabolites that have become interesting and significant resources for drug discovery [1-3]. Morinda officinalis, known as one of the 'top four south authentic traditional Chinese medicines', has obvious regional characteristics. Its roots contain plant sterols, anthraquinones, flavonoids, vitamin $C$, sugar, resin and other ingredients, and they are widely used to treat impotence, spermatorrhea, rheumatism and female infertility [4]. However, there are few systematic reports on endophytic fungus resources from this plant and their active components. During our ongoing search aimed at structurally unique and bioactive substances from endophytic fungi [5-8], we conducted a chemical analysis on a fraction of the broth extract of the fungus Alternaria sp. A744 derived from M. officinalis, which led to the isolation of two new secondary metabolites along with eleven known compounds (Figure 1). All the compounds were evaluated for their cytotoxic and $\alpha$-glucosidase inhibitory activities via assays. Herein, the details of the isolation, structural elucidation and bioassay are described. 
<smiles>COC(=O)CC1OC(=O)c2c(O)cccc21</smiles><smiles>CC(=O)CC1(O)C(=O)c2cccc(O)c2C1=O</smiles>

2<smiles>[R]C1=C([R])C([R2])C([R4])([R4])c2cc([R])cc(O)c2C1=O</smiles>

$3 \mathrm{R}_{1}=\mathrm{H}, \mathrm{R}_{2}=\mathrm{OH}, \mathrm{R}_{3}=\mathrm{H}, \mathrm{R}_{4}=\mathrm{H}, \mathrm{R}_{5}=\mathrm{H}, \mathrm{R}_{6}=\mathrm{H}$ $4 \mathrm{R}_{1}=\mathrm{H}, \mathrm{R}_{2}=\mathrm{OH}, \mathrm{R}_{3}=\mathrm{H}, \mathrm{R}_{4}=\mathrm{H}, \mathrm{R}_{5}=\mathrm{H}, \mathrm{R}_{6}=\mathrm{OH}$ $5 \mathrm{R}_{1}=\mathrm{H}, \mathrm{R}_{2}=\mathrm{OH}, \mathrm{R}_{3}=\mathrm{H}, \mathrm{R}_{4}=\mathrm{OH}, \mathrm{R}_{5}=\mathrm{H}, \mathrm{R}_{6}=\mathrm{H}$ $6 \mathrm{R}_{1}=\mathrm{OH}, \mathrm{R}_{2}=\mathrm{OH}, \mathrm{R}_{3}=\mathrm{H}, \mathrm{R}_{4}=\mathrm{H}, \mathrm{R}_{5}=\mathrm{H}, \mathrm{R}_{6}=\mathrm{H}$ $7 \mathrm{R}_{1}=\mathrm{OH}, \mathrm{R}_{2}=\mathrm{H}, \mathrm{R}_{3}=\mathrm{OH}, \mathrm{R}_{4}=\mathrm{OH}, \mathrm{R}_{5}=\mathrm{H}, \mathrm{R}_{6}=\mathrm{H}$

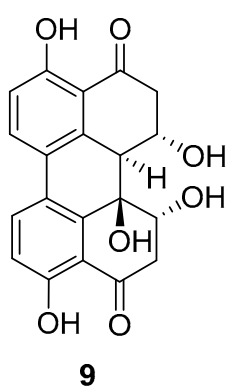<smiles>O=C1CC[C@]2(O)c3c(ccc(O)c31)-c1ccc(O)c3c1[C@@]2(O)[C@H](O)CC3=O</smiles>

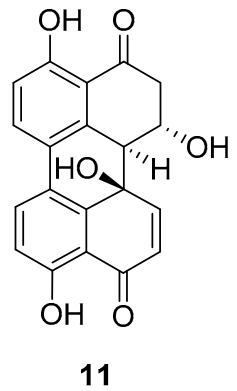

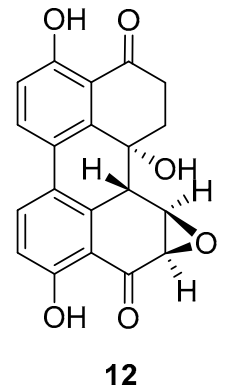<smiles>O=C1CC(O)[C@@H]2c3c(ccc(O)c31)[C@H](O)C(=O)CC2O</smiles>

Figure 1. Structures of compounds 1-13 isolated from Alternaria sp. A744.

\section{Results}

\subsection{Structural Elucidation of New Compounds}

Isobenzofuranone $A(\mathbf{1})$, colorless oil, had a molecular formula of $\mathrm{C}_{11} \mathrm{H}_{10} \mathrm{O}_{5}$ on the basis of negative high-resolution electrospray ionization mass spectra (HR-ESI-MS) $\left([\mathrm{M}-\mathrm{H}]^{-} m / z\right.$ 221.0460, calcd. for 221.0450), corresponding to seven degrees of unsaturation (see Figures S1-S9). The infrared spectroscopy (IR) spectrum exhibited absorption bands at 3435 (hydroxyl group) and 1732 (carbonyl group) $\mathrm{cm}^{-1}$. The ${ }^{1} \mathrm{H}-\mathrm{NMR}$ spectroscopic data of $\mathbf{1}$ (Table 1) combined with heteronuclear multiple quantum coherence (HMQC) experiment implied one methoxy signal [ $\delta_{\mathrm{H}} 3.72$ $\left.\left(\mathrm{s}, J=1.1, \mathrm{H}_{3}-10\right)\right]$, one methylene signal $\left[\delta_{\mathrm{H}} 3.08(\mathrm{dd}, J=16.6,4.6), 2.80(\mathrm{dd}, J=16.6,8.0)\right]$, one methine $\left[\delta_{\mathrm{H}} 5.82(\mathrm{dd}, J=8.0,4.6, \mathrm{H}-3)\right]$ and three aromatic protons $\left[\delta_{\mathrm{H}} 6.90(\mathrm{~d}, J=8.2, \mathrm{H}-6), 7.00(\mathrm{~d}, J=7.4\right.$, $\mathrm{H}-4), 7.55$ (dd, $J=8.2,7.4, \mathrm{H}-5)]$. The ${ }^{13} \mathrm{C}-\mathrm{NMR}$ spectrum revealed 11 carbon resonances attributed to two carbonyl groups $\left(\delta_{C} 171.2,171.5\right)$, a methoxyl carbon $\delta_{C} 52.4(\mathrm{C}-10)$, one methylene carbon $\delta_{C} 40.0(\mathrm{C}-8)$, three sp ${ }^{2}$ quaternary carbons [ $\delta_{C} 158.4(\mathrm{C}-7), 152.2(\mathrm{C}-3 \mathrm{a}), 112.5(\mathrm{C}-7 \mathrm{a})$ ], and three $\mathrm{sp}^{2}$ methine carbons $\left[\delta_{\mathrm{C}} 113.9(\mathrm{C}-4), 137.8(\mathrm{C}-5), 117.1(\mathrm{C}-6)\right]$. The COSY correlations between $\mathrm{H}-4\left(\delta_{\mathrm{H}} 7.00\right)$ and $\mathrm{H}-5\left(\delta_{\mathrm{H}} 7.55\right), \mathrm{H}-5$ and $\mathrm{H}-6\left(\delta_{\mathrm{H}} 6.9\right)$ confirmed the presence of 1,2,3-trisubstituted benzene moiety. The benzene ring along with two carbonyl groups accounted for six unsaturation degrees, while the remaining degrees of unsaturation indicated that an additional ring must be present in the molecule. Meanwhile, a signal of ${ }^{13} \mathrm{C}-\mathrm{NMR}$ resonance at $\delta_{\mathrm{C}} 171.5$ and an absorption in the IR spectrum at $1732 \mathrm{~cm}^{-1}$ suggested the presence of a lactone carbonyl group. These data showed a great resemblance to the known compound isoochracinic acid [9], the only difference between them is that a hydroxyl group at position C-10 in the known compound was replaced by a methoxy group in 1 . Furthermore, the heteronuclear multiple bond correlation (HMBC) correlations (Figure 2) from methine proton $\mathrm{H}-3$ $\left(\delta_{\mathrm{H}} 5.82\right)$ to $\mathrm{C}-1$ and $\mathrm{C}-7 \mathrm{a}, \mathrm{H}_{2}-8$ to $\mathrm{C}-1$ and $\mathrm{C}-3 \mathrm{a}$, as well as $\mathrm{H}-6$ to $\mathrm{C}-7 \mathrm{a}$ and $\mathrm{C}-1$ secured the connection of $\mathrm{C}-3$ and $\mathrm{C}-1$ to the aromatic ring. Simultaneously, the relative downfield chemical shift of C-3 $\left(\delta_{\mathrm{C}} 78.9\right)$ revealed a connection with oxygen, thereby forming a lactone ring. The HMBC cross-peaks from $\mathrm{H}-3$ and the proton of methoxy $\mathrm{H}_{3}-10\left(\delta_{\mathrm{H}} 3.72\right)$ to $\mathrm{C}-9$ determined the presence of a methyl acetate unit in 1. The critical COSY signals (Figure 2) from $\mathrm{H}-3$ to $\mathrm{H}_{2}-8$ suggested that the methylene group 
was directly connected to the lactone ring at C-3. Thus, the planar structure of $\mathbf{1}$ was determined, as shown in Figure 1.

Table 1. ${ }^{1} \mathrm{H}-\mathrm{NMR}(500 \mathrm{MHz})$ and ${ }^{13} \mathrm{C}-\mathrm{NMR}(125 \mathrm{MHz})$ data for $\mathbf{1}$ and 2 in $\mathrm{CD}_{3} \mathrm{OD}$.

\begin{tabular}{|c|c|c|c|c|}
\hline \multirow{2}{*}{ No. } & \multicolumn{2}{|l|}{1} & \multicolumn{2}{|l|}{2} \\
\hline & $\delta_{H}(J$ in $\mathrm{Hz})$ & $\delta_{\mathrm{C}}$ & $\delta_{H}(J$ in $\mathbf{H z})$ & $\delta_{C}$ \\
\hline 1 & & $171.2, \mathrm{C}$ & & 200.7, C \\
\hline 2 & & & & $73.8, \mathrm{C}$ \\
\hline 3 & $5.82(\mathrm{dd}, 8.0,4.6)$ & $78.4, \mathrm{CH}$ & & $200.8, C$ \\
\hline $3 a$ & & $152.2, \mathrm{C}$ & & $143.4, \mathrm{C}$ \\
\hline 4 & $7.00(\mathrm{~d}, 7.4)$ & $113.9, \mathrm{CH}$ & $7.44(\mathrm{~d}, 7.4)$ & $115.5, \mathrm{CH}$ \\
\hline 5 & $7.55(\mathrm{dd}, 8.2,7.4)$ & $137.8, \mathrm{CH}$ & $7.77(\mathrm{dd}, 8.2,7.4)$ & $139.1, \mathrm{CH}$ \\
\hline 6 & $6.90(\mathrm{~d}, 8.2)$ & $117.1, \mathrm{CH}$ & $7.28(\mathrm{~d}, 8.2)$ & $124.4, \mathrm{CH}$ \\
\hline 7 & & $158.4, \mathrm{C}$ & & $158.3, \mathrm{C}$ \\
\hline $7 \mathrm{a}$ & & $112.5, \mathrm{C}$ & & $127.4, \mathrm{C}$ \\
\hline 8 & $3.08(\mathrm{dd}, 16.6,4.6)$ & $40.0, \mathrm{CH}_{2}$ & $3.37(\mathrm{~d}, 2.5)$ & $49.5, \mathrm{CH}_{2}$ \\
\hline & $2.80(\mathrm{dd}, 16.6,8.0)$ & & & \\
\hline 9 & & $171.5, \mathrm{C}$ & & 208.1, C \\
\hline 10 & $3.72(\mathrm{~s})$ & $52.4, \mathrm{CH}_{3}$ & $2.09(\mathrm{~s})$ & $29.3, \mathrm{CH}_{3}$ \\
\hline
\end{tabular}

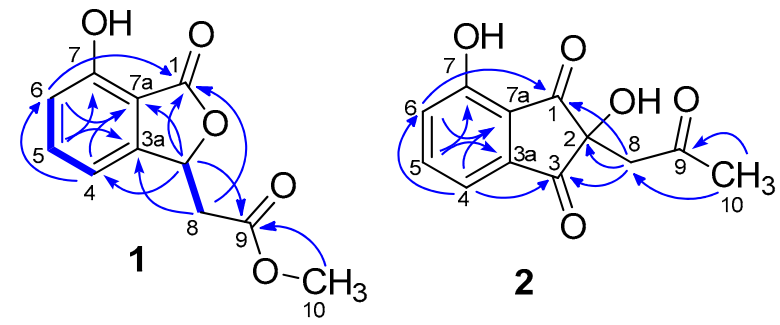

Figure 2. $\operatorname{Key}{ }^{1} \mathrm{H}^{-1} \mathrm{H} \operatorname{COSY}(-)$ and $\mathrm{HMBC}(\frown)$ correlations for compounds $\mathbf{1}, 2$.

Indandione B (2) was obtained as yellow oil. HRESIMS analysis of 2 revealed a molecular formula $\mathrm{C}_{12} \mathrm{H}_{10} \mathrm{O}_{5}\left([\mathrm{M}-\mathrm{H}]^{-} \mathrm{m} / z\right.$ 233.0467, calcd. for 233.0450), corresponding to eight degrees of unsaturation (see Figures S10-S17). The IR spectrum exhibited absorption bands at 3377 (hydroxyl group), 1743 and 1703 (carbonyl groups) $\mathrm{cm}^{-1}$. The ${ }^{1} \mathrm{H}-\mathrm{NMR}$ data of 2 (Table 1 ) revealed one methoxy signal [ $\delta_{\mathrm{H}} 2.09$ $\left.\left(\mathrm{s}, \mathrm{H}_{3}-10\right)\right]$, one methylene $\left[\delta_{\mathrm{H}} 3.37\left(\mathrm{~d}, J=2.5, \mathrm{H}_{2}-8\right)\right]$, and one 1,2,3-trisubstituted benzene moiety $\left[\delta_{\mathrm{H}} 7.28(\mathrm{~d}, J=8.2, \mathrm{H}-6), 7.44(\mathrm{~d}, J=7.4, \mathrm{H}-4), 7.77(\mathrm{dd}, J=7.4,8.2, \mathrm{H}-5)\right]$. The ${ }^{13} \mathrm{C}-\mathrm{NMR}$ spectrum and the HMQC revealed 12 carbon resonances attributed to one methyl, one methylene, three methines, and seven quaternary carbons. The abovementioned information was quite similar to that of the known compound indanostatin, which was isolated from Streptomyces sp. [10]. They all have a typical indandione five-membered ring structure, except for the absence of a hydroxyl group at position $\mathrm{C}-4$ and a methyl group at position $\mathrm{C}-5$ on the benzene ring in 2. The HMBC correlations from H-4 to C-3, C-6 and C-7a, H-5 to C-3a and C-7, H-6 to C-3a, C-7a, and C-1, along with the HMBC cross-peaks between $\mathrm{H}-8$ to $\mathrm{C}-1, \mathrm{C}-2$, and $\mathrm{C}-3$, secured the presence of an indandione five-membered ring. Moreover, the $\mathrm{HMBC}$ correlations (Figure 2) from $\mathrm{H}_{2}-8$ and $\mathrm{H}_{3}-10$ to $\mathrm{C}-9$ implied the presence of a 2-oxopropyl unit in 2. Finally, the HMBC cross-peaks of methylene protons with C-1, C-2 and C-3 suggested that the 2-oxopropyl group was connected with the indandione five-membered ring at C-2. Therefore, the planar structure of 2 was assigned, as shown in Figure 1.

The known compounds were determined as isosclerone (3) [11], 2,4,8-trihydroxy-1-tetralone (4) [9], 3,4-dihydro-3,4,8-trihydroxy-1[2H]-naphthalenone (5) [12], 6-hydroxyisosclerone (6) [13], cis-4-hydroxyscytalone (7) [14], alternariol-4-methyl ether (8) [15], 6-epi-stemphytriol (9) [16], dihydroalterperylenol (10) [17], alterperylenol (11) [16], altertoxin II (12) [18,19], and stemphyperylenol (13) [20], by spectroscopic analysis and comparison with previous reports in literature. 


\subsection{In Vitro Cytotoxicity Assay}

The in vitro cytotoxic activity of compounds 1-13 was investigated against four tumor cell lines, including MCF-7, HepG-2, NCI-H460 and SF-268, by the SRB (Sulforhodamine B) method with cisplatin as the positive control. As outlined in Table 2, compounds $\mathbf{1 1}$ and $\mathbf{1 2}$ showed significant inhibitory activities against the four tumor cell lines with $\mathrm{IC}_{50}$ values in the range of $1.91-9.67 \mu \mathrm{M}$.

Table 2. Cytotoxic activity of compounds 1-13.

\begin{tabular}{ccccc}
\hline \multirow{2}{*}{ Compounds } & \multicolumn{4}{c}{ IC $_{\mathbf{5 0}}(\boldsymbol{\mu M})$} \\
\cline { 2 - 5 } & MCF-7 & HepG-2 & NCI-H460 & SF-268 \\
\hline $\mathbf{1 - 8}$ & $\geq 100$ & $\geq 100$ & $\geq 100$ & $\geq 100$ \\
$\mathbf{9}$ & $35.73 \pm 1.61$ & $52.38 \pm 2.46$ & $43.31 \pm 1.75$ & $49.04 \pm 1.84$ \\
$\mathbf{1 0}$ & $\geq 100$ & $\geq 100$ & $\geq 100$ & $\geq 100$ \\
$\mathbf{1 1}$ & $3.73 \pm 0.33$ & $5.30 \pm 0.95$ & $5.47 \pm 0.26$ & $6.57 \pm 0.35$ \\
$\mathbf{1 2}$ & $1.91 \pm 0.17$ & $5.63 \pm 0.10$ & $9.67 \pm 0.22$ & $4.25 \pm 0.01$ \\
$\mathbf{1 3}$ & $\geq 100$ & $\geq 100$ & $\geq 100$ & $\geq 100$ \\
Cisplatin & $3.09 \pm 0.27$ & $1.39 \pm 0.18$ & $2.43 \pm 0.15$ & $2.37 \pm 0.35$ \\
\hline
\end{tabular}

\section{3. $\alpha$-Glucosidase Inhibitory Activity Assay}

Simultaneously, all compounds were further evaluated for their $\alpha$-glucosidase inhibitory activity. Compounds 4, 5, 9, 10, 12 and 13 showed excellent inhibitory activity against $\alpha$-glucosidase with $\mathrm{IC}_{50}$ values in the range of $12.05-166.13 \mu \mathrm{M}$ (Table 3), which was obviously stronger than the positive control of acarbose ( $\left.\mathrm{IC}_{50}=427.34 \mu \mathrm{M}\right)$.

Table 3. $\alpha$-Glucosidase inhibitory activities of compounds 4, 5, 9, 10, 12 and 13.

\begin{tabular}{cc}
\hline Compounds & $\alpha$-glucosidase $\left(\mathrm{IC}_{\mathbf{5 0}, \boldsymbol{\mu M})}\right.$ \\
\hline $\mathbf{4}$ & $34.88 \pm 1.59$ \\
$\mathbf{5}$ & $102.34 \pm 2.45$ \\
$\mathbf{9}$ & $141.43 \pm 7.66$ \\
$\mathbf{1 0}$ & $74.94 \pm 2.70$ \\
$\mathbf{1 2}$ & $12.05 \pm 2.06$ \\
$\mathbf{1 3}$ & $166.13 \pm 2.81$ \\
\hline Acarbose & $427.34 \pm 12.03$ \\
\hline
\end{tabular}

\section{Materials and Methods}

\subsection{General Experimental Material}

Optical rotations were determined on an Anton Paar MCP-500 spectropolarimeter (Anton Paar, Graz, Austria) at room temperature. UV spectra were recorded on a Shimadzu UV-2600 spectrophotometer (Shimadzu, Kyoto, Japan). IR spectra were measured using a Shimadzu IR Affinity-1 spectrometer (Shimadzu, Kyoto, Japan). 1D and 2D NMR spectra were performed on a Bruker Avance-500 spectrometer with tetramethylsilane (TMS) as an internal standard (Bruker, Fällanden, Switzerland). ESIMS was measured by an Agilent Technologies 1290-6430A Triple Quad LC/MS (Agilent Technologies, Palo Alto, CA, USA). HRESIMS were done with a Thermo MAT95XP high resolution mass spectrometer (Thermo Fisher Scientific, Bremen, Germany). A Shimadzu LC-20 AT (Shimadzu, Kyoto, Japan) equipped with a SPD-M20A PDA detector was used for HPLC, and a YMC-pack ODS-A/AQ column $(250 \mathrm{~mm} \times 20 \mathrm{~mm}, 5 \mu \mathrm{m}, 12 \mathrm{~nm})$ was used for semi-preparative HPLC separation. Column chromatography (CC): silica gel (200-300 mesh; Qingdao Marine Chemical Inc., Qingdao, China), C-18 reversed phase silica gel (40-63 $\mu \mathrm{m}$, Merck, Darmstadt, Germany), and Sephadex LH-20 gel (Pharmacia Fine Chemical Co. Ltd., Uppsala, Sweden). Silica gel 
$60 \mathrm{GF}_{254}$ glass plates (Merck, Darmstadt, Germany) were used for thin layer chromatography (TLC) spotting. All solvents used were of analytical grade (Guangzhou Chemical Regents Company, Ltd., Guangzhou, China). $\alpha$-Glucosidase from Saccharomyces cerevisiae was purchased from Sigma (St. Louis, MO, USA).

\subsection{Fungal Material}

The endophytic fungal strain A744 was isolated from the twigs of Morinda officinalis, which was collected from Gaoyao city, Guangdong province of China, in January 2015. The strain A744 was identified by sequence analysis of rDNA ITS (internal transcribed spacer) region. The sequence of the ITS region of the strain has been submitted to GenBank (Accession No. KF706672). By using BLAST (nucleotide sequence comparison program) to search the GenBank database, A744 has 100\% similarity to Alternaria sp. MY-2011 (Accession No. JN038490). The strain was preserved at the Guangdong Provincial Key Laboratory of Microbial Culture Collection and Application, Guangdong Institute of Microbiology.

\subsection{Fermentation, Extraction and Compound Isolation}

The fungal strain Alternaria sp. A744 was cultivated on potato-dextrose agar (PDA) medium at $28^{\circ} \mathrm{C}$ for 5 days, and then plugs of agar supporting mycelial growth were cut into small pieces and transferred aseptically into five Erlenmeyer flasks $(500 \mathrm{~mL})$, each containing $250 \mathrm{~mL}$ potato-dextrose broth, and incubated on a rotary shaker for 5 days at $28^{\circ} \mathrm{C}$ at $120 \mathrm{r} / \mathrm{min}$ to prepare the seed culture. Then, $10 \mathrm{~mL}$ of the seed culture was inoculated into a total of 600 Erlenmeyer flasks $(500 \mathrm{~mL})$ containing $250 \mathrm{~mL}$ culture broth for 7 days under the same conditions. The culture $(150 \mathrm{~L})$ was filtered to separate the broth and mycelia. The broth was extracted five times with EtOAc, while the mycelia were homogenized and saturated with $\mathrm{MeOH}$ by the ultrasonic extraction method. The EtOAc crude extract (7.1 g) was subjected to column chromatography (CC) on Sephadex $\mathrm{LH}-20\left(\mathrm{CH}_{2} \mathrm{Cl}_{2} / \mathrm{MeOH}, 1: 1, v / v\right)$ to obtain four fractions (A-D) based on TLC monitoring.

Fraction $\mathrm{D}(3.5 \mathrm{~g})$ was further purified on $\mathrm{C}_{18}$ reversed phase silica gel and eluted with a gradient of $\mathrm{MeOH} / \mathrm{H}_{2} \mathrm{O}(v / v, 3: 7 \rightarrow 10: 0)$ to yield eight major fractions (D1-D8). Subfraction D2 (1.7 g) was separated by a silica gel CC to give five fractions (D2.1-D2.5). D2.2 was subjected to a semi-preparative $\mathrm{HPLC}\left(\mathrm{ACN} / \mathrm{H}_{2} \mathrm{O}, 30: 70,3 \mathrm{~mL} / \mathrm{min}\right)$, then a secondary preparation HPLC $\left(\mathrm{MeOH} / \mathrm{H}_{2} \mathrm{O}, 40: 60\right.$, $3 \mathrm{~mL} / \mathrm{min})$ to afford compounds $\mathbf{1}(4.6 \mathrm{mg})$ and $3(8.0 \mathrm{mg})$. D2.3 was further separated by Sephadex LH-20 $\left(\mathrm{CH}_{2} \mathrm{Cl}_{2} / \mathrm{MeOH}, 1: 1, v / v\right)$, following a silica gel CC (Hexane/Acetone, 8:1 $\left.\rightarrow 2: 1, v / v\right)$ and a semi-preparative $\mathrm{HPLC}\left(\mathrm{ACN} / \mathrm{H}_{2} \mathrm{O}, 15: 85,3 \mathrm{~mL} / \mathrm{min}\right)$ to obtain compounds $2(6.0 \mathrm{mg}), 4(8.4 \mathrm{mg})$ and 5 (2.2 mg). D2.4 was separated by Sephadex LH-20 (Acetone), following a silica gel CC to yield compound 6 (9.2 mg). D2.5 was separated by a silica gel CC, following a Sephadex LH-20 (Acetone) and a preparation HPLC $\left(\mathrm{ACN} / \mathrm{H}_{2} \mathrm{O}, 10: 90,3 \mathrm{~mL} / \mathrm{min}\right)$ to afford compound $7(2.7 \mathrm{mg})$. D3 $(125.3 \mathrm{mg})$ was further purified on Sephadex LH-20 $(\mathrm{MeOH})$, following a semi-preparative HPLC $\left(\mathrm{MeOH} / \mathrm{H}_{2} \mathrm{O}\right.$, $55: 45,3 \mathrm{~mL} / \mathrm{min}$ ) to obtain compound $9(17.0 \mathrm{mg})$. D4 (101.1 $\mathrm{mg})$ was applied onto a semi-preparative HPLC (MeOH/ $\left.\mathrm{H}_{2} \mathrm{O}, 45: 55,3 \mathrm{~mL} / \mathrm{min}\right)$ to acquire compound 10 (13.4 mg). D5 (46.9 mg) was displayed in the same way as D4 to give compound $\mathbf{1 1}(20.5 \mathrm{mg})$. Fraction D7 $(26.3 \mathrm{mg})$ was subjected to a silica gel CC, following a Sephadex LH-20 (Acetone) to obtain compound $\mathbf{1 2}(2.0 \mathrm{mg})$. Compound $\mathbf{8}(3.0 \mathrm{mg})$ was separated from D8 $(66.1 \mathrm{mg})$ by a silica gel CC and a semi-preparative HPLC $\left(\mathrm{MeOH} / \mathrm{H}_{2} \mathrm{O}, 80: 30\right.$, $3 \mathrm{~mL} / \mathrm{min})$. Finally, compound $\mathbf{1 3}(6.0 \mathrm{mg})$ was isolated from mycelia using a silica gel CC, following a semi-preparative HPLC $\left(\mathrm{MeOH} / \mathrm{H}_{2} \mathrm{O}, 50: 50,3 \mathrm{~mL} / \mathrm{min}\right)$.

\subsection{Spectroscopic Data}

Isobenzofuranone A (1): colorless oil; $[\alpha]_{\mathrm{D}}^{25}+2.9$ (c 0.1, MeOH); $\mathrm{UV}(\mathrm{MeOH}) \lambda_{\max }(\log \varepsilon) 211$ (4.11), 233 (3.56), 299 (3.38) nm; IR $v_{\max }$ 3435, 2955, 2920, 2851, 1732, 1607, 1468, 1285, 1161, $1003 \mathrm{~cm}^{-1}$; ESIMS negative $m / z 221.0$ [M - H] ${ }^{-}$; HRESIMS $m / z 221.0460[\mathrm{M}-\mathrm{H}]^{-}\left(\right.$calcd. for $\mathrm{C}_{11} \mathrm{H}_{9} \mathrm{O}_{5}, 221.0450$ ); and ${ }^{1} \mathrm{H}(500 \mathrm{MHz})$ and ${ }^{13} \mathrm{C}(125 \mathrm{MHz})$ NMR data, see Table 1. 
Indandione B (2): yellow oil; $[\alpha]_{\mathrm{D}}^{25}-4.3(c 0.1, \mathrm{MeOH}) ; \mathrm{UV}(\mathrm{MeOH}) \lambda_{\max }(\log \varepsilon) 201$ (4.03), 235 (3.02), 334 (3.57) $\mathrm{nm}$; IR $\gamma_{\max } 3377,2924,2853,1744,1703,1601,1464,1290,1177,1020 \mathrm{~cm}^{-1}$; ESIMS negative $\mathrm{m} / \mathrm{z}$ $233.0[\mathrm{M}-\mathrm{H}]^{-}$; HRESIMS $\mathrm{m} / z 233.0467[\mathrm{M}-\mathrm{H}]^{-}$(calcd. for $\left.\mathrm{C}_{12} \mathrm{H}_{9} \mathrm{O}_{5}, 233.0450\right)$; and ${ }^{1} \mathrm{H}(500 \mathrm{MHz})$ and ${ }^{13} \mathrm{C}(125 \mathrm{MHz})$ NMR data, see Table 1.

\subsection{In Vitro Cytotoxicity Assay}

The in vitro cytotoxic activities of compounds (1-13) were assayed against four human tumor cell lines MCF-7, HepG-2, NCI-H460 and SF-268, with cisplatin as a positive control. Assays were performed by the SRB method [21].

\section{6. $\alpha$-Glucosidase Inhibitory Activity Assay}

An assay of $\alpha$-glucosidase inhibitory activity was evaluated according the method previously published in Reference [22].

\section{Conclusions}

In this study, thirteen compounds, including two new ones, were isolated from Alternaria sp., an endophytic fungus from Morinda officinalis. All the structures were established by extensive spectroscopic analysis. The isolates were evaluated their cytotoxicities against four human tumor cell lines and $\alpha$-glucosidase inhibitory activity assays. Compounds $\mathbf{1 1}$ and $\mathbf{1 2}$ exhibited significant inhibitory activities with $\mathrm{IC}_{50}$ values in the range of 1.91-9.67 $\mu \mathrm{M}$. Compounds 4, 5, 9, 10, 12 and 13 showed excellent inhibitory activity against $\alpha$-glucosidase, which might be useful for further developing $\alpha$-glucosidase inhibitor.

Supplementary Materials: Supplementary material relating to this article can be accessed online.

Acknowledgments: Financial support for this research was provided by the National Natural Science Foundation of China (No. 31600271), by the Basic Research Program of China (973 Program) (No. 2014CB460613), by the Guangdong Provincial Project for Science and Technology (No. 2014A030304050, 2015A030302060), by the Natural Science Foundation of Guangdong Province (No. 2015A030313710), and by the GDAS' Special Project of Science and Technology Development (No. 2017GDASCX-0819).

Author Contributions: Wei-Min Zhang conceived and designed the experiments and reviewed the manuscript; Ying Wang, Yu-Chan Chen, Hao-Hua Li, Sai-Ni Li and Ming-Li Yan performed the experiments; Hong-Xin Liu and Zhang-Hua Sun analyzed the data; Ying Wang and Hong-Xin Liu wrote the paper. All authors read and approved the final manuscript.

Conflicts of Interest: The authors declare no conflict of interest.

\section{References}

1. Aly, A.H.; Debbab, A.; Kjer, J.; Proksch, P. Fungal endophytes from higher plants: A prolific source of phytochemicals and other bioactive natural products. Fungal Divers. 2010, 41, 1-16. [CrossRef]

2. Wang, G.W.; Huang, B.K.; Qin, L.P. The genus Broussonetia: A review of its phytochemistry and pharmacology. Phytother. Res. 2012, 26, 1-10. [CrossRef] [PubMed]

3. Schulz, B.; Boyle, C.; Draeger, S.; Römmert, A.K.; Krohn, K. Endophytic fungi: A source of novel biologically active secondary metabolites. Mycol. Res. 2002, 106, 996-1004. [CrossRef]

4. Pharmacopoeia Committee of China. Pharmacopoeia of People's Republic of China; China Medical Science and Technology Press: Beijing, China, 2015; pp. 81-82.

5. Wang, M.; Sun, Z.H.; Chen, Y.C.; Liu, H.X.; Li, H.H.; Tan, G.H.; Li, S.N.; Guo, X.L.; Zhang, W.M. Cytotoxic cochlioquinone derivatives from the endophytic fungus Bipolaris sorokiniana derived from Pogostemon cablin. Fitoterapia 2016, 110, 77-82. [CrossRef] [PubMed]

6. Sun, Z.H.; Liang, F.L.; Wu, W.; Chen, Y.C.; Pan, Q.L.; Li, H.H.; Ye, W.; Liu, H.X.; Li, S.N.; Tan, G.H.; et al. Guignardones P-S, new meroterpenoids from the endophytic fungus Guignardia mangiferae A348 derived from the medicinal plant Smilax glabra. Molecules 2015, 20, 22900-22907. [CrossRef] [PubMed] 
7. Liu, H.X.; Tan, H.B.; Liu, Y.; Chen, Y.C.; Li, S.N.; Sun, Z.H.; Li, H.H.; Qiu, S.X.; Zhang, W.M. Three new highly-oxygenated metabolites from the endophytic fungus Cytospora rhizophorae A761. Fitoterapia 2017, 117, 1-5. [CrossRef] [PubMed]

8. Sun, Z.H.; Li, H.H.; Liang, F.L.; Chen, Y.C.; Liu, H.X.; Li, S.N.; Tan, G.H.; Zhang, W.M. Two new secondary metabolites from the endophytic Fungus Endomelanconiopsis endophytica. Molecules 2016, 21, 943. [CrossRef] [PubMed]

9. Stierle, A.A.; Upadhyay, R.; Hershenhorn, J.; Strobel, G.A.; Molina, G. The phytotoxins of Mycosphaerella fijiensis, the causative agent of Black Sigatoka disease of bananas and plantains. Experientia 1991, 47, 835-859. [CrossRef]

10. Hayakawa, Y.; Kobayash, T.; Izawa, M. Indanostatin, a new neuroprotective compound from Streptomyces sp. J. Antibiot. 2013, 66, 731-733. [CrossRef] [PubMed]

11. Kokubun, T.; Veitch, N.C.; Bridge, P.D.; Simmonds, M.S.J. Dihydroisocoumarins and a tetralone from Cytospora eucalypticola. Phytochemistry 2003, 62, 779-782. [CrossRef]

12. Iwasaki, S.; Muro, H.; Sasaki, K.; Nozoe, S.; Okuda, S.; Sato, Z. Isolations of phytotoxic substances produced by Pyricularia oryzae Cavara. Tetrahedron Lett. 1973, 14, 3537-3542. [CrossRef]

13. Dong, J.Y.; Song, H.C.; Li, J.H.; Tang, Y.S.; Sun, R.; Wang, L.; Zhou, Y.P.; Wang, L.M.; Shen, K.Z.; Wang, C.R.; et al. Ymf 1029A-E, preussomerin analogues from the fresh-eater-derived fungus YMF 1.01029. J. Nat. Prod. 2008, 71, 952-956. [CrossRef] [PubMed]

14. Bell, A.A.; Stipanovic, R.D.; Puhalla, J.E. Pentaketide metabolites of Verticillium dahlia. Identification of (+)-scytalone as anatural proecursor to melanin. Tetrahedron 1976, 32, 1353-1356. [CrossRef]

15. Tan, N.; Tao, Y.; Pan, J.; Wang, S.; Xu, F. Isolation, structure elucidation, and mutagenicity of four alternariol derivatives produced by the mangrove endophytic fungus No. 2240. Chem. Nat. Compd. 2008, 44, 296-300. [CrossRef]

16. Li, D.M.; Wu, X.; Ji, X.C.; Wu, X.Y.; Bai, J.; Pei, Y.H. Secondary metabolites of endophyte fungus Alternaria tenuissima SY-P-07. Chin. Pharm. J. 2014, 49, 464-468.

17. Zhang, S.Y.; Li, Z.L.; Bai, J.; Wang, Y.; Zhang, L.M.; Wu, X.; Hua, M.H. A new perylenequinone from a halotolerant fungus, Alternaria sp. M6. Chin. J. Nat. Med. 2012, 10, 68-71. [CrossRef] [PubMed]

18. Stack, M.E.; Mazzola, E.P.; Page, S.W.; Pohland, A.E.; Highet, R.J. Mutagenic perylenequinone metabolites of Alternaria alternata: Altertoxins I, II, and III. J. Nat. Prod. 1986, 52, 866-871. [CrossRef]

19. Sun, J.Y.; Awakawa, T.; Noguchi, H.; Abe, I. Induced production of mycotoxins in an endophytic fungus from the medicinal plant Datura stramonium L. Bioorg. Med. Chem. Lett. 2012, 22, 6397-6400. [CrossRef] [PubMed]

20. Zheng, C.J.; Fu, X.M.; Zhang, X.L.; Kong, W.W.; Wang, C.Y. Bioactive perylene derivatives from a soft coral-derived fungus Alternaria sp. (ZJ-2008017). Chem. Nat. Compd. 2015, 51, 766-768. [CrossRef]

21. Skehan, P.; Storeng, R.; Scudiero, D.; Monks, A.; McMahon, J.; Vistica, D.; Warren, J.T.; Bokesch, H.; Kenney, S.; Boyd, M.R. New colorimetric cytotoxicity assay for anticancer-drug screening. J. Natl. Cancer Inst. 1990, 82, 1107-1112. [CrossRef] [PubMed]

22. Liu, Y.Y.; Yang, Q.; Xia, G.P.; Huang, H.B.; Li, H.X.; Ma, L.; Lu, Y.J.; He, L.; Xia, X.K.; She, Z.G. Polyketides with $\alpha$-glucosidase inhibitory activity from a mangrove endophytic fungus, Penicillium sp. HN29-3B1. J. Nat. Prod. 2015, 78, 1816-1822. [CrossRef] [PubMed]

Sample Availability: Samples of the compounds of 1-13 are available from the authors. 